\title{
Clinical and histopathological profile of patients with ovarian cyst presenting in a tertiary care hospital of Kashmir, India
}

\author{
Rizwana Habib Kant*, Shagufta Rather, Sabia Rashid
}

Department of Obstetrics and Gynaecology, Government Medical College, Srinagar, Jammu and Kashmir, India

Received: 12 June 2016

Accepted: 02 July 2016

\section{*Correspondence:}

Dr. Rizwana Habib Kant,

E-mail: habibrizwana@gmail.com

Copyright: (c) the author(s), publisher and licensee Medip Academy. This is an open-access article distributed under the terms of the Creative Commons Attribution Non-Commercial License, which permits unrestricted non-commercial use, distribution, and reproduction in any medium, provided the original work is properly cited.

\begin{abstract}
Background: Ovary is the commonest site of physiological and pathological lesions which can present in any age group and are common gynaecological problems encountered by gynaecologists in their daily practice.

Aims: To find the clinical and histopathological profile of patients with ovarian cysts in Kashmir valley and to determine regional variation if any.

Methods: This was an observational study conducted in the Postgraduate Department of Gynaecology and Obstetrics, Lalla Ded Hospital, Government Medical College over a period of two years from March 2014 to March 2016 of 160 patients after obtaining ethical clearance from the institutional ethical committee. All the cases of ovarian cysts sent for histopathological examination were included in the study. Data included age, parity, clinical symptoms, intraoperative findings and histopathological findings.

Results: The mean age of presentation was 33.9 years. Most ovarian tumours occurred in 30 - 39 years of age. Dull abdominal pain was the most common clinical presentation. Of the 160 patients studied, the incidence of benign tumour was $71.87 \%$, borderline tumour was $1.9 \%$ and malignant tumour was $28.12 \%$. The most common type of ovarian cysts was serous cystadenoma (22.5\%) followed by mucinous cystadenoma (19.4\%). Bilateral ovarian involvement was seen in $13.1 \%$ cases.

Conclusions: Benign ovarian tumours were more common than malignant ones in all age groups. A higher incidence of malignancy was observed in our study as compared to other studies, showing regional variations and highlighting the need to identify region specific risk factors.
\end{abstract}

Keywords: Ovarian cyst, Benign, Malignant, Regional variation

\section{INTRODUCTION}

Ovarian neoplasms are the common gynaecological problems encountered by gynaecologists in their daily practice. They can be seen in all age groups and can be physiological or pathological cysts. Physiological cysts are mainly follicular and luteal cysts and need no treatment unless cysts are complicated. Pathological cysts can be benign or malignant. Benign tumors are more common in young females while as malignant ones are common in elderly females. ${ }^{1}$ The incidence of ovarian cancers is approximately $30 \%$ of all the gynaecological malignancies. ${ }^{2}$ Ovarian cancer is most fatal gynaecological malignancy because of late detection and absence of any specific symptoms and signs in early stages of disease. According to World Health Organization histological classification, ovarian tumors are subdivided into 9 main categories as per tissue of origin -surface epithelial tumors, sex cord stromal tumors, lipid cell tumors, germ cell tumors, gonandoblastomas, soft tissue tumors not specific to the ovary, unclassified tumours, metastatic tumors and tumour like conditions. ${ }^{3}$ About 70 to $80 \%$ of primary ovarian tumors are of epithelial origin, $10 \%$ of stromal origin and $5 \%$ of germ cell origin, while remainder fall in other categories. ${ }^{3}$ Epithelial tumors can be split into 5 
basic histological groups - serous $(80 \%)$, mucinous $(5 \%)$, endometrioid (10\%), clear cell $(5 \%)$ and brenners tumors $^{4}$. In the first two decades of life, almost $70 \%$ of ovarian tumors are of germ cell origin, and one third of these are malignant. ${ }^{4}$ The most common type of malignant germ cell tumours are dysgerminomas, immature teratomas, and endodermal sinus tumours. Sex cord stromal tumours include granulosa, theca, sertoli or leydig cell tumours. Mature cystic teratoma is the most common benign tumour followed by benign serous tumour.

Metastatic tumours to the ovaries are most frequently from the breast and gastrointestinal tract. ${ }^{4}$

The present study was conducted to find the clinical and histopathological profile of patients with ovarian cysts in Kashmir valley and to determine regional variation if any.

\section{METHODS}

This is an observational study conducted in the Postgraduate Department of Gynaecology and Obstetrics, Lalla Ded Hospital, Government Medical College over a period of two years from March 2014 to March 2016 of 160 patients after obtaining ethical clearance from the institutional ethical committee. All the patients who presented with ovarian cysts and had to be operated were included in the study. Data included age, parity, clinical symptoms, intra-operative findings and histopathological findings.

\section{Statistical methods}

The recorded data was compiled and entered in a spreadsheet (Microsoft Excel) and then exported to data editor of SPSS Version 16.0 (SPSS Inc., Chicago, Illinois, USA). Descriptive Statistics of data including the mean and standard deviation for numerical variables and the percentages of different categories for categorical variables was obtained. Frequency distribution tables, bar and pie charts were used for data presentation.

\section{RESULTS}

From March 2014 to March 2016, a total of 160 patients with ovarian cysts subjected to surgery and histopathological examination were studied. The mean age of the patients was $33.9 \pm 12.24$ years. The age range was from 15 years to 70 years. Ovarian cysts were commonly seen in age group between 30 - 39 years (Figure 1).

The number of nulliparous patients were 53 out of 160 $(33.12 \%)$ while as the number of parous (para 1, para 2, para 3) patients were 107 out of $160(66.9 \%$ ) (Figure 2).

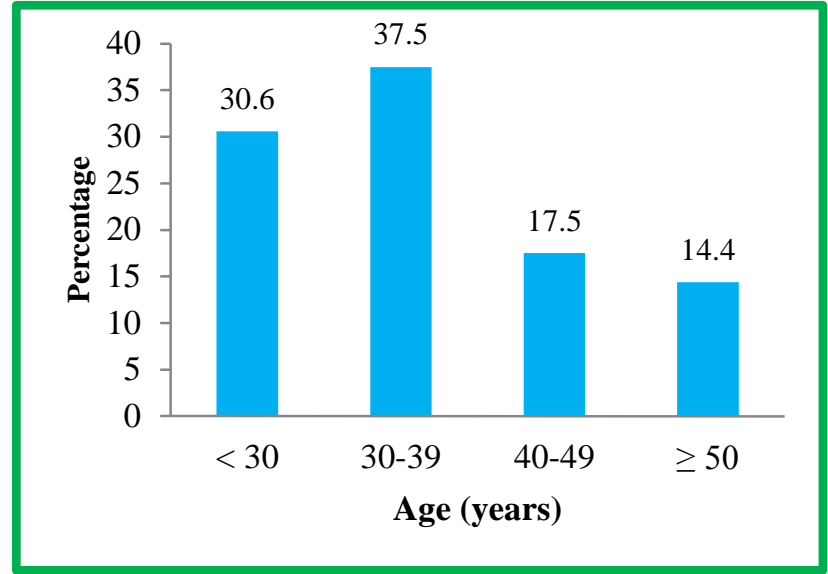

Mean age in years: $33.9 \pm 12.24$. Age range: 15 - 70 years.

Figure 1: Age distribution of studied patients.

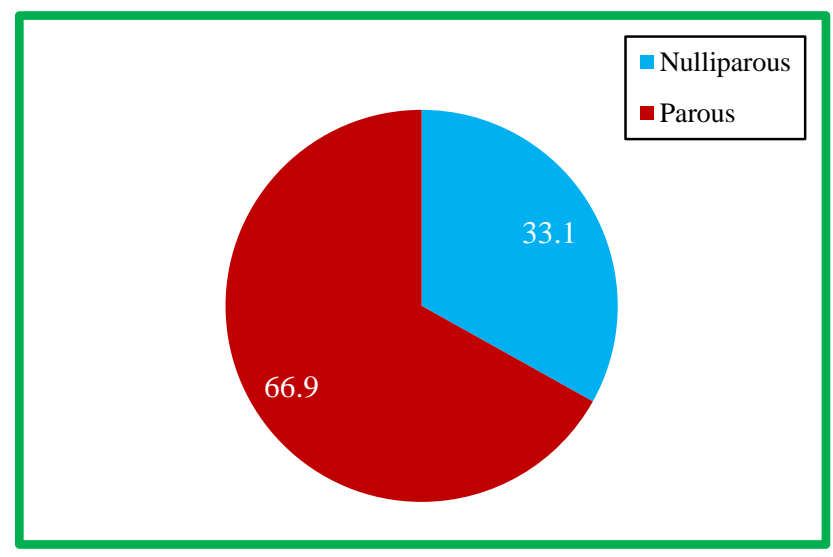

Figure 2: Distribution of parity in studied patients.

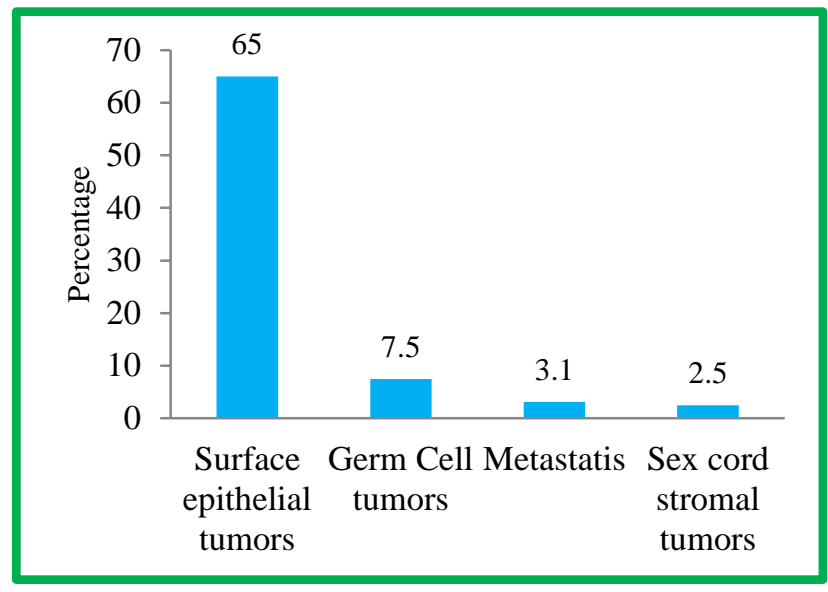

Figure 3: Type of ovarian tumors according to WHO classification.

In this study bilateral ovarian involvement was seen in $13.1 \%$ of cases (21 out of 160), right ovary was involved in 64 out of 160 cases $(40 \%)$ and left ovary was involved in 75 cases $(46.8 \%)$. 
Table 1: Clinical presentation in studied patients.

\begin{tabular}{|llll|}
\hline $\begin{array}{l}\text { Clinical } \\
\text { presentation }\end{array}$ & $\begin{array}{l}\text { No. of } \\
\text { patients }\end{array}$ & Benign & Malignant \\
\hline Pain lower abdomen & 63 & 50 & 13 \\
\hline Menorrhagia & 3 & & 3 \\
\hline Amenorrhoea & 10 & 2 & 8 \\
\hline Polymenorrhagia & 17 & 9 & 8 \\
\hline Abdominal lump & 16 & 8 & 8 \\
\hline Retention of urine & 7 & 5 & 2 \\
\hline $\begin{array}{l}\text { Post-menopausal } \\
\text { bleeding }\end{array}$ & 4 & 1 & 3 \\
\hline $\begin{array}{l}\text { Pain lower abdominal } \\
+ \text { Swelling }\end{array}$ & 40 & 27 & 13 \\
\hline Total & 160 & 100 & \\
\hline
\end{tabular}

Table 2: Histopathological findings in studied patients.

\begin{tabular}{|c|c|c|}
\hline Histopathological Findings & $\begin{array}{l}\text { No. of } \\
\text { patients }\end{array}$ & Percentage \\
\hline $\begin{array}{l}\text { Signet ring cell carcinoma } \\
\text { (metastasis) }\end{array}$ & 5 & 3.1 \\
\hline Dysgerminoma & 4 & 2.5 \\
\hline Mucinous cystadenoma & 31 & 19.4 \\
\hline Serous cystadenoma & 36 & 22.5 \\
\hline $\begin{array}{l}\text { Haemorrhagic corpus luteal } \\
\text { cyst }\end{array}$ & 24 & 15.1 \\
\hline $\begin{array}{l}\text { Sertoli leydig tumour with } \\
\text { mucinous cyst adenocarcinoma }\end{array}$ & 2 & 1.25 \\
\hline Granulosa - stromal tumour & 2 & 1.25 \\
\hline $\begin{array}{l}\text { Mucinous } \\
\text { cystadenocarcinoma }\end{array}$ & 17 & 10.6 \\
\hline Inflammatory cyst & 5 & 3.1 \\
\hline Mature cystic teratoma & 8 & 5.0 \\
\hline Endometriotic cyst & 6 & 3.8 \\
\hline $\begin{array}{l}\text { Serous borderline ovarian } \\
\text { tumour }\end{array}$ & 3 & 1.9 \\
\hline $\begin{array}{l}\text { Papillary serous cyst } \\
\text { adenofibroma }\end{array}$ & 4 & 2.5 \\
\hline Serous cystadenocarcinoma & 13 & 8.1 \\
\hline Total & 160 & 100 \\
\hline
\end{tabular}

Table 3: Association of age with histopathological findings in studied patients.

\begin{tabular}{|lllll|}
\hline $\begin{array}{l}\text { Age } \\
\text { (years) }\end{array}$ & \multicolumn{2}{l}{ Benign $(\mathrm{n}=\mathbf{1 1 4})$} & \multicolumn{2}{l|}{ Malignant $(\mathrm{n}=\mathbf{4 6})$} \\
\hline$<30$ & 36 & Percentage & No. & Percentage \\
\hline $30-39$ & 43 & 37.6 & 13 & 28.3 \\
\hline $40-49$ & 17 & 14.9 & 17 & 37.0 \\
\hline$\geq 50$ & 18 & 15.8 & 5 & 11 \\
\hline
\end{tabular}

Table 1 shows $39.4 \%$ of patients presented with pain lower abdomen, $25 \%$ of patients presented with pain and swelling, $10.6 \%$ with polymenorrhagia, $10.0 \%$ with abdominal lump, $6.3 \%$ patients with amenorrhoea, $4.4 \%$ with retention of urine, $2.5 \%$ patients with postmenopausal bleeding and $1.9 \%$ with menorrhagia.

In this study, $65.6 \%$ of patients had benign features intra operatively while as $34.3 \%$ of patients had malignant features intra operatively.

Among 160 cases, $71.87 \%$ (115) of ovarian cysts were benign and $28.12 \%$ (45) were malignant on histopathology.

Histopathological reports revealed, ovarian cyst was serous cystadenoma type in $22.5 \%$, mucinous cystadenoma type in $19.4 \%$, mucinous cystadenocarcinoma (10.6\%), haemorrhagic corpus luteal cyst type in $15.1 \%$, serous cystadenocarcinoma $8.1 \%$, mature cystic teratoma 5\%, and others (Table 2).

Figure 5 shows commonest type of tumour as per WHO classification was surface epithelial tumours $(65 \%)$ followed by germ cell tumour $(7.5 \%)$ followed by sex cord stromal tumours $(2.5 \%)$. Metastasis was seen in $3.1 \%$ of cases.

Benign tumours were common in all age groups as compared to malignant tumours. A higher incidence of malignancy was found in the age group 30-39 years (Table 3).

\section{DISCUSSION}

The current study was undertaken among 160 patients who presented in tertiary care hospital of Kashmir valley from March 2014 to March 2016.

The mean age of presentation was $33.9 \pm 12.24$ years. The age range was from 15 years to 70 years which was comparable to the study conducted by Pudasaini S et al. ${ }^{1}$

Out of total 160 cases, bilateral ovarian involvement was seen in 13.1 cases. Similar findings were seen in a study conducted by Pudasaini $\mathrm{S}$ et al, Kayastha et al. ${ }^{1,5}$

The most common presentation was lower abdominal pain $(39.4 \%)$ followed by pain and swelling (25\%), followed by lump in the abdomen $(10 \%)$ in our study which was comparable in the study conducted by Deepti Vijay et al. ${ }^{6}$

The incidence of benign tumour was $71.87 \%$, borderline tumour was $1.9 \%$ and malignant tumour was $28.12 \%$ in our study which was comparable to study conducted by Vijay D et al. ${ }^{6}$ In the study conducted by Kanthikar SN. ${ }^{7}$ $78.57 \%$ cases were benign, borderline tumours was $1.42 \%$ and $20 \%$ cases were malignant.

In our study, the commonest type of ovarian tumour according to WHO classification was surface epithelial tumour $(65 \%)$, followed by germ cell tumour $(7.5 \%)$ 
followed by sex cord stromal tumour (2.5\%). This was comparable to study conducted by Pudasaini S et al. ${ }^{1}$

Among the benign surface epithelial tumours, the most common tumour was serous cystadenoma (22.5\%) (Figure 4) followed by mucinous cystadenoma (19.4\%) which was comparable to the study conducted by Pudasaini $S$ et al. ${ }^{1}$

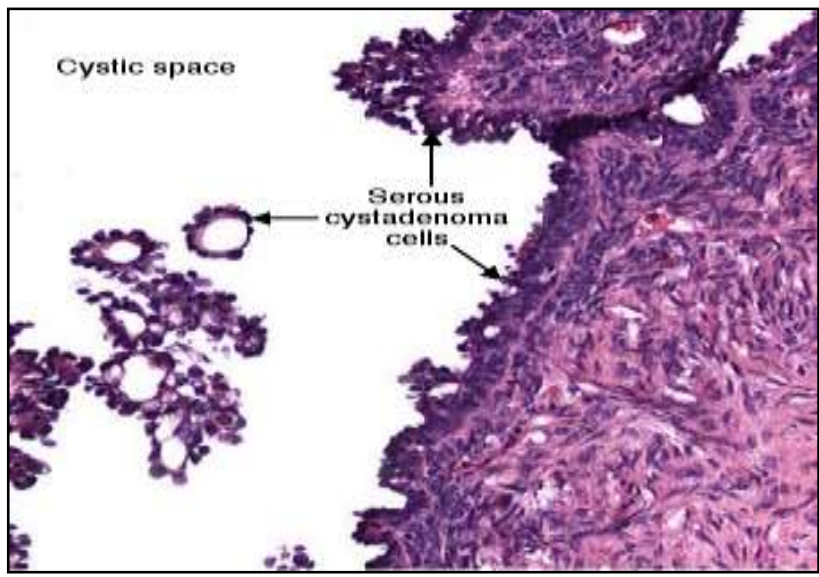

Figure 4: Serous cystadenoma.

Among the malignant epithelial surface tumours, mucinous cystadenocarcinoma (10.6\%) (Figure 5) was the commonest followed by serous cystadenocarcinoma $(8.1 \%)$ in our study. In the studies conducted by Deepti Vijay et al, Zaman $\mathrm{S}$ et al, serous cystadenocarcinoma was the commonest malignant epithelial surface tumour. 6,8

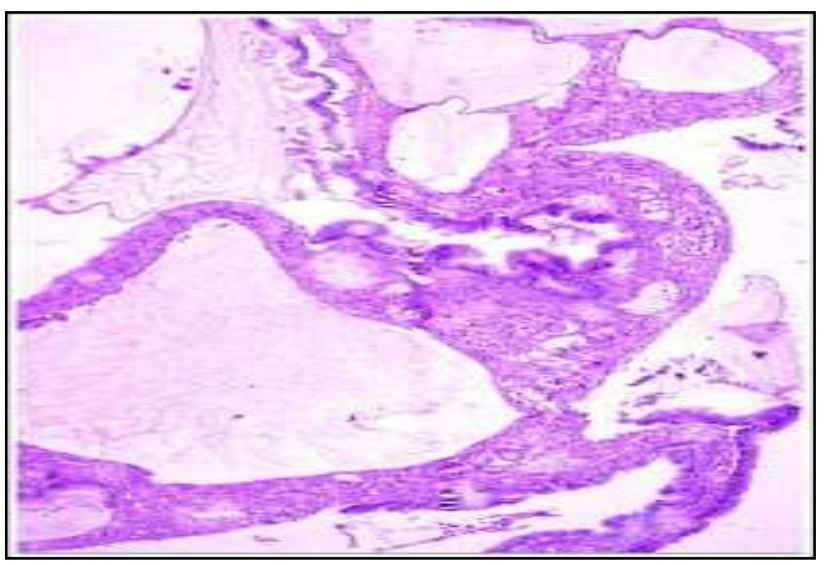

Figure 5: Mucinous cystadenocarcinoma.

Germ cell tumour was the second $(7.5 \%)$ most common tumour in our study with mature cystic teratoma $(5 \%)$ being commonest followed by dysgerminoma (2.5\%). In the studies conducted by Pudasaini S et al, Vijay D et al, most common germ cell tumour was mature cystic tumour which was comparable to our study.
Our study showed $2.5 \%$ cases of sex cord stromal tumours which was comparable to the studies conducted by Pudasaini $\mathrm{S}$ et al, Jha et al. ${ }^{1,9}$

Metastasis to ovary was seen in $3.1 \%$ of cases in our study and most common metastasis was from gastro intestinal tract. In the study conducted by Pudasaini $\mathrm{S}$ et al, metastasis to ovary was seen in $6.9 \%$ of cases. Powari et al, found metastasis to ovary in $5 \%$ of cases in their study. 1,10

Other benign cysts in our study were haemorrhagic corpus luteal cyst (15.1\%) and endometriosis (3.8\%). This was comparable to the study conducted by Pudasaini $\mathrm{S}$ et al. ${ }^{1}$. In the study conducted by Choi et al $(2003)^{11}$, corpus luteal cysts were the most common among the haemorrhagic ovarian cysts.

A majority of the tumours diagnosed in our study occurred in the 30-39 years of age. Higher incidence (37\%) of malignancy was found in the age group of 3039 years of age group. In the study conducted by Vijay D et al majority of tumours occurred in the 21- 40 years of age group and significant proportion $(35 \%)$ of ovarian malignancies was found in women younger than 40 years. ${ }^{6}$

\section{CONCLUSION}

The present hospital based study analyzed 160 ovarian cysts with respect to their clinical and histopathological profile. Lower abdominal pain was the most common clinical presentation. Benign tumours were more common than malignant ones across all age groups. A lower incidence of metastatic tumour was found in our study compared to other studies. On histopathological examination, tumours originating from the surface epithelium were the most common variant. Though majority of the tumours were benign, a higher incidence of malignancy was observed in our study as compared to other studies. The higher incidence of malignancy in our study could be because of intra- regional variation. It is, therefore, proposed that further studies should be made to identify risk factors for ovarian oncogenesis existing in different regions.

\section{Funding: No funding sources \\ Conflict of interest: None declared}

Ethical approval: The study was approved by the Institutional Ethics Committee

\section{REFERENCES}

1. Pudasaini S, Lakhey M, Hirachand S, Akhter J, Thapa B: A study of ovarian cyst in a tertiary hospital of Kathmandu valley. Nepal Med Coll J. 2011;13(1):39-41.

2. Ramesh N, Arya A, Kusum N, Agarwal K, Agarwal A, Singh S. Overview of benign and malignant 
tumours of female genital tract. Journal of Applied Pharmaceutical Science. 2013;3(01):140-9.

3. Kumar P, Malhotra N. Jeffcoate's Principles of Gynaecology - Seventh edition. 2008.

4. Berek and Novak's Gynaecology, $15^{\text {th }}$ edition. Lippincott Williams and Wilkins, 2012, 1560 pp

5. Kayastha S. Study of ovarian tumors in Nepal Medical College Teaching Hospital. Nepal Med Coll J. 2009; 11:200-2.

6. Mankar DV, Jain GK. Histopathological profile of ovarian tumours: A twelve year institutional experience. Muller J Med Sci Res. 2015;6:11.

7. Kanthikar SN, Dravid NV, Deore PN, Nikumbh DB, Suryawanshi KH. Clinico-Histopathological Analysis of Neoplastic and Non-Neoplastic Lesions of the Ovary: A 3-Year Prospective Study in Dhule, North Maharashtra, India J Clin Diagn Res. 2014;8(8):FC04-7.
8. Zaman S, Majid S, Hussain M, Chughtai O, Mahboob J, Chughtai S. A retrospective study of ovarian tumours and tumour-like lesions. J Ayub Med Coll Abbottabad. 2010;22:104-8.

9. Jha R, Karki S. Histological pattern of ovarian tumours and their age distribution. Nepal Med Coll J. 2008; 10:81-5.

10. Powari M, Dey P, Gupta SK, Saha S. Metastatic tumors of the ovary: a clinicopathological study. Indian J Pathol Microbiol. 2003;46:412-5.

11. Choi HJ, Kim SH, Kim SH. Ruptured corpus luteal cyst: CT findings. Korean J Radiol. 2003;4:42-5.

Cite this article as: Kant RH, Rather S, Rashid S. Clinical and histopathological profile of patients with ovarian cyst presenting in a tertiary care hospital of Kashmir, India. Int J Reprod Contracept Obstet Gynecol 2016;5:2696-2700. 